\title{
Differential distribution of cathepsin B in human umbilical cord tissues
}

\author{
Tomasz Gogiel ${ }^{\Downarrow}$, Zofia Galewska and Lech Romanowicz \\ Department of Medical Biochemistry, Medical Academy of Białystok, Poland
}

The extracellular matrix components are differentially distributed among various structures of the umbilical cord. Wharton's jelly is especially rich in collagens and growth factors. Cathepsin B is a major cysteine protease involved in collagen degradation, as well as in the activation of precursor forms of other collagenolytic enzymes and growth factors. We assessed the activity and expression of cathepsin B in the umbilical cord arteries, veins and Wharton's jelly. Extracts of separated umbilical cord components were subjected to an activity assay with the use of specific fluorogenic substrate. The expression of cathepsin B protein was qualitatively evaluated by Western immunoblotting and quantitatively determined with an immunoenzymatic method. The total cathepsin B activity and content calculated per gram of DNA were higher in Wharton's jelly than in the umbilical cord vessels, and the latter parameter was the lowest in the umbilical cord arteries. Moreover, the expression and the activity of latent cathepsin B (following activation by pepsin digestion) calculated per gram of DNA were the highest in Wharton's jelly and the lowest in the umbilical cord arteries. High expression and activity of latent, pepsin-activatable cathepsin B related to DNA content in Wharton's jelly seem to reflect the stimulation of its cells by high amounts of collagen I and growth factors.

Key words: cathepsin B; pregnancy; umbilical cord, umbilical cord artery; umbilical cord vein; Wharton's jelly

Received: 14 August, 2012; revised: 12 October, 2012; accepted: 07 November, 2012; available on-line: 27 November, 2012

\section{INTRODUCTION}

The intrauterine development of the foetus is strongly influenced by the vascular system of the mother and of the placenta. The umbilical cord (UC) forms a structure connecting the foetus with the placenta. It contains two arteries and one vein embedded in Wharton's jelly (WJ), which is covered by simple amniotic epithelium (Bańkowski, 1999). The umbilical cord arteries (UCAs) transport deoxygenated blood and metabolic waste products from the foetus to the placenta, whereas the umbilical cord vein (UCV) delivers oxygen and nutrients to the foetus (Kliman, 1998). The extracellular matrix (ECM) in the vascular wall provides many macromolecules (collagens, elastin, proteoglycans and structural proteins) necessary for the structural and functional properties of the vessel wall (Jacob et al., 2001).

Wharton's jelly is a jelly-like substance consisting of very few cells immersed in abundant ECM components, mainly collagen, hyaluronate and several proteoglycans containing various sulphated glycosaminoglycan chains (Nanaev et al., 1997; Sobolewski et al., 1997; Bańkowski, 1999; Gogiel et al., 2003). Additionally, many peptide growth factors have been detected in this tissue (Sobolewski et al., 2005; Małkowski et al., 2008). The high ECM content has been suggested to provide hydration, elasticity and mechanical resistance to compression and extension, sufficient to prevent the occlusion of the UC vessels caused by foetal movements and uterine contraction (Takechi et al., 1993; Nanaev et al., 1997; Sobolewski et al., 2005). The cells of WJ were previously described as myofibroblasts as they possess ultrastructural characteristics of both smooth muscle cells and fibroblasts. They may be involved in the regulation of umbilical blood flow due to their contractile properties and contribute to the elasticity of WJ by synthesising collagen fibres (Takechi et al., 1993; Kobayashi et al., 1998).

Cathepsin B (EC 3.4.22.1; CATB) is a ubiquitous lysosomal cysteine proteinase (Mort \& Buttle, 1997). It is synthesized as a preproenzyme containing 339 amino acids (Chan et al., 1986), converted to an inactive latent precursor, glycosylated and processed to an active single-chain form. The conversion into an active doublechain CATB occurs in lysosomes, the final localisation of the enzyme (Mort \& Buttle, 1997; Cavallo-Medved \& Sloane, 2003).

Cathepsin B exhibits broad substrate specificity at both acidic and neutral pH (Keppler \& Sloane, 1996). It participates in ECM degradation and remodelling, either by direct proteolysis of matrix components or by activating other proteases (Cavallo-Medved \& Sloane, 2003). Cathepsin B directly degrades various ECM proteins, including different collagen types, fibronectin, laminin, aggrecan core protein and elastin (Poręba et al., 2002; Baici et al., 2005; Skrzydlewska et al., 2005). The indirect role of cathepsin B involves the extracellular activation of latent forms of other enzymes of the proteolytic cascade mediating ECM degradation, like matrix metalloproteinases, urokinase plasminogen activator (Schmitt et al., 1997; Skrzydlewska et al., 2005) and cathepsin D. Active forms of these enzymes participate in activation of other cathepsins and metalloproteinases or directly degrade ECM constituents, leading to the release of vari-

e-mail: tgogiel@umb.edu.pl

Abbreviations: AMC, 7-amido-4-methylcoumarin; CATB, cathep$\sin$ B; CHAPS, 3-[(3-cholamidopropyl)dimethylammonio]-1-propane-sulphonate; EDTA, ethylenediaminetetraacetic acid; GAPDH, glyceraldehyde-3-phosphate dehydrogenase; ECM, extracellular matrix; hc-CATB, heavy chain of double-chain cathepsin B; PDGF, platelet-derived growth factor; pro-CATB, procathepsin B; SC-CATB, single-chain cathepsin $B$; TGF- $\beta$, transforming growth factor-beta; UC, umbilical cord; UCA, umbilical cord artery; UCV, umbilical cord vein; WJ, Wharton's jelly. 
ous growth factors in a form accessible to cell receptors, which in turn can influence the cell growth and matrix synthesis (Skrzydlewska et al., 2005). Cathepsin B can also directly activate growth factors, e.g. the latent form of TGF-31 (Guo et al., 2002; Andl et al., 2010).

The distribution of cathepsin B in the umbilical cord has not been studied to date. We hypothesized that the peculiarities of WJ, such as the very low content of cells, abundance of ECM components (Nanaev et al., 1997; Sobolewski et al., 2005) and peptide growth factors (Sobolewski et al., 2005; Małkowski et al., 2008), may influence and/ or result from specific metabolism of CATB in this tissue. In order to elucidate the role of cathepsin B in the metabolism of UC tissues, we decided to assess the activity and expression of this enzyme in Wharton's jelly and compare them with those of the UC vessels - arteries and vein.

\section{MATERIALS AND METHODS}

The investigation protocol was approved by the Committee for Ethics and Supervision on Human and Animal Research of the Medical University of Białystok.

Tissue material. Studies were performed on the umbilical cord arteries, umbilical cord veins and Wharton's jelly taken from 10 newborns delivered by healthy mothers aged 20-30. The babies were born between 36 and 41 weeks of gestation. The mean body weight of the newborns was $3540 \pm 453 \mathrm{~g}$. In all cases, sections $(20 \mathrm{~cm}$ long) of the umbilical cords were excised beginning from their placental end. UC vessels were carefully separated from the surrounding Wharton's jelly immediately after delivery. All the tissues were stored at $-70^{\circ} \mathrm{C}$.

Preparation of tissue extracts. Fragments of UCAs, UCVs and WJ were washed with ice-cold $0.9 \% \mathrm{NaCl}$ solution, cut into small pieces, blotted, weighed and suspended in a cold extraction phosphate buffer $(88 \mathrm{mM}$ $\mathrm{K}_{2} \mathrm{PO}_{4}, 12 \mathrm{mM} \mathrm{NaHPO}$ ), $\mathrm{pH} 6.0$, containing $4 \mathrm{mM}$ EDTA, and $0.5 \%(\mathrm{w} / \mathrm{v})$ CHAPS, in the ratio of $200 \mathrm{mg}$ of fresh tissue per $1 \mathrm{ml}$ of the buffer. They were homogenized with the use of a knife homogenizer (Ultra Turrax; $25000 \mathrm{rpm}, 4 \times 15 \mathrm{~s}$, breaks of $15 \mathrm{~s}$, at $\left.0^{\circ} \mathrm{C}\right)$. The homogenates were incubated on ice (for $10 \mathrm{~min}$ ), vortexed (for $5 \mathrm{~min}$, at $0^{\circ} \mathrm{C}$ ) and centrifuged $(18000 \times \mathrm{g}$, for $30 \mathrm{~min}$, at $2^{\circ} \mathrm{C}$ ). The supernatants (tissue extracts) were collected, aliquoted and stored at $-70^{\circ} \mathrm{C}$ until further analysis was performed.

Cathepsin B activity assay. CATB was determined according to the modified method of Barrett \& Kirschke (1981) adapted to performing the assay in 96-well black microtiter plates. The final incubation mixture included fluorogenic substrate N-CBZ-L-arginyl-L-arginyl-7-amido4-methylcoumarin (Z-Arg-Arg-AMC; Peptide Institute, Inc.; $10 \mu \mathrm{M}$ ) in $0.1 \mathrm{M}$ phosphate buffer, $\mathrm{pH}$ 6.0, containing $2 \mathrm{mM}$ EDTA and $2 \mathrm{mM}$ dithiothreitol. Fluorescence of the released 7-amido-4-methylcoumarin (AMC) was followed continuously with a Tecan Infinite ${ }^{\circledR} 200$ PRO microplate reader (Tecan Group Ltd.) at the excitation and emission wavelengths of 354 and $442 \mathrm{~nm}$, respectively. Initial rates were monitored for less than $5 \%$ total substrate hydrolysis. Duplicate samples additionally included a specific CATB inhibitor, $5 \mathrm{mM} \mathrm{N}$ L-3-trans-propylcarbamoyloxirane-2-carbonyl)-L-isoleucylL-proline (CA-074; Bachem). The difference between values without and with CA-074 corresponded to CATB activity. One unit of enzyme activity (U) was defined as the amount of enzyme sufficient to release $1 \mu \mathrm{mol}$ of product (AMC) per minute at $37^{\circ} \mathrm{C}$. Latent CATB was activated with pepsin as previously described (Koblinski et al., 2002) with the following modifications. Briefly, $100 \mu \mathrm{l}$ of UCV, UCA and WJ extracts, $100 \mu \mathrm{M}$ AMC in the extraction buffer (standard), or the extraction buffer alone (negative control) were incubated with $25 \mu$ l of $0.2 \mathrm{M}$ sodium formate buffer, $\mathrm{pH} 3.3$, containing $4 \mathrm{mM}$ EDTA and $0.9 \mathrm{mg} / \mathrm{ml}$ pepsin, for $60 \mathrm{~min}$ at $37^{\circ} \mathrm{C}$. Duplicate samples were incubated on ice in the absence of pepsin. The reaction was stopped by the addition of 275 $\mu \mathrm{l}$ of $0.1 \mathrm{M}$ phosphate buffer, $\mathrm{pH} 6.7$, containing $4 \mathrm{mM}$ EDTA. Such activated or non-activated samples were then used for CATB activity determination. The activities determined for samples incubated with pepsin were defined as total CATB activities. The values for samples incubated in the absence of pepsin corresponded to active CATB activities. The differences between total and active CATB activities were defined as latent CATB activities.

Western blot analysis. Tissue extracts of UCA, UCV and WJ were thawed, pooled and mixed with a protease inhibitor cocktail (catalogue number P8340; Sigma) in a ratio 100:1 (v/v). Then denaturing buffer containing SDS $(1.5 \%)$ and 2 -mercaptoethanol $(10 \%$; final concentrations) was added and the samples were heated at $95^{\circ} \mathrm{C}$ for $5 \mathrm{~min}$. The samples $(20 \mu \mathrm{g}$ of protein) were electrophoresed on $10 \%$ SDS-polyacrylamide gel according to the method of Laemmli (1970), blotted to nitrocellulose membranes (Sigma) and blocked with 5\% (w/v) nonfat powdered milk in TBS-T $(20 \mathrm{mM}$ Tris/ $\mathrm{HCl}$ buffer, $\mathrm{pH} 7.4,150 \mathrm{mM} \mathrm{NaCl}, 0.05 \%$ (v/v) Tween 20) for 1 hour. They were then incubated with rabbit polyclonal antibodies directed against human cathepsin B (catalogue number sc-13985; Santa Cruz Biotechnology Inc.; 1:200) or glyceraldehyde-3-phosphate dehydrogenase (GAPDH; catalogue number G9545; Sigma; 1:10000) in the blocking solution, overnight at $4^{\circ} \mathrm{C}$. Bound antibodies were detected using alkaline phosphatase-conjugated goat anti-rabbit secondary antibody (Sigma) and BCIP/NBT reagent (catalogue number B1911; Sigma). Three experiments were carried out for each pooled tissue sample.

Determination of cathepsin B content. A quantitative analysis of CATB antigen in tissue extracts was performed using an ELISA kit from Biosensis (catalogue number BEK-2163-2P).

Determination of DNA in tissue homogenates. DNA determination was performed by the fluorimetric method of Downs and Wilfinger (1983), with the use of bis-benzimidazole Hoechst 33258 dye (catalogue number B2883; Sigma) and modifications including performing the assay in a 96-well plate. Herring sperm DNA (catalogue number 223646; Boehringer Mannheim $\mathrm{GmbH}$ ) was used as a standard.

Protein assay. Protein content in the tissue extracts was determined by the method of Bradford (1976).

Statistical analysis. The data with a normal distribution (DNA content, Pro-/Active cathepsin B ratio) were tested with repeated measures ANOVAs. Tukey HSD post-hoc testing was applied to compare differences among results obtained for matched UCA, UCV and WJ samples from individual umbilical cords. The other data were analysed with Friedman ANOVAs and post-hoc analyses by multiple Wilcoxon signed-ranks tests corrected by Bonferroni-Holm method. Data are presented as the mean values from 10 assays \pm standard deviation (S.D.) or as the median values \pm 25 th and 75 th quartiles $(\mathrm{n}=10)$, for repeated measures and Friedman ANOVAs, respectively. A $P<0.05$ was considered as statistically significant. Statistical analysis was performed using Statistica 10 program (StatSoft, Inc; Hill \& Lewicki, 2007). 


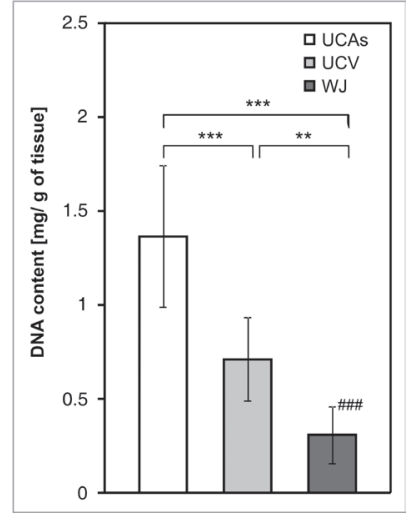

Figure 1. DNA content in umbilical cord tissues.

Fluorimetric assay with the use of bis-benzimidazole Hoechst 33258 dye reagent was applied. DNA contents are calculated per one gram of umbilical cord arteries (UCAs), umbilical cord vein (UCV) and Wharton's jelly (WJ). Mean values \pm standard deviations (S.D.) are presented $(n=10)$. Data are analyzed with repeated measures one-way ANOVA (\#\#P $<0.001)$ and post hoc Tukey HSD tests $\left.{ }^{* *} \mathrm{P}<0.01 ;{ }^{* * * *} \mathrm{P}<0.001\right)$

\section{RESULTS}

\section{DNA content}

Figure 1 presents DNA content in the UC tissue extracts. Wharton's jelly contained approximately 4.5 times less DNA per gram of tissue in comparison to the UCAs and almost 2.5 times less than the UCV (Fig. 1; $P<0.001$ and $P<0.01$, respectively).

\section{Cathepsin B activity}

The activities of cathepsin B calculated per one milligram of DNA contained in the UC tissues are depicted in Fig. 2. WJ demonstrated over 4 times higher total CATB activity in comparison to the UCAs and almost 2.5 times higher than in the UCV $(P<0.05)$. Active and latent CATB forms showed similar distribution of activity within the UC tissues, although in

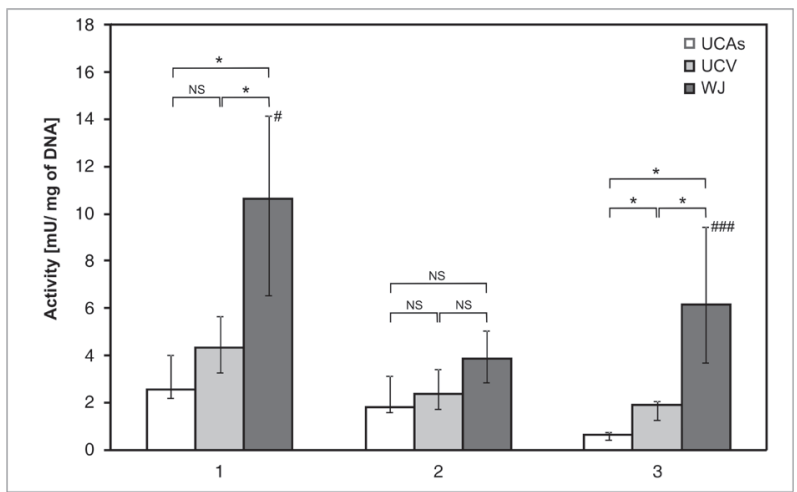

Figure 2. Activity of cathepsin B in umbilical cord tissues.

The extracts of umbilical cord arteries (UCAs), umbilical cord vein (UCV) and Wharton's jelly (WJ) were assayed with the use of ZArg-Arg-AMC as a specific substrate. The activities of total (1), active (2) and latent (pepsin-activatable; 3 ) cathepsin B are calculated per one milligram of DNA contained in umbilical cord tissues. Median values \pm 25 th and 75 th quartiles are presented $(n=10)$. Data are analyzed with Friedman repeated-measures ANOVA $(\# P<0.05$; \#\#P<0.001), post-hoc comparisons made with the Wilcoxon's signed-ranks test corrected for multiple comparisons using the Bonferroni-Holm method (adjusted $P$-values: ${ }^{*} P<0.05$; NS, non-significant difference).

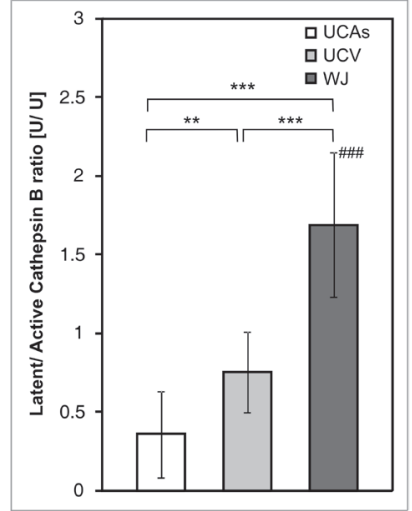

Figure 3. Latent/active cathepsin B ratio in umbilical cord tissues.

The activities of cathepsin B in umbilical cord arteries (UCAs), umbilical cord vein (UCV) and Wharton's jelly (WJ) were measured with the use of Z-Arg-Arg-AMC as a specific substrate. Mean values \pm standard deviations (S.D.) are presented $(n=10)$. Data are analyzed with repeated measures one-way ANOVA $(\# \# P<0.001)$ and post hoc Tukey HSD tests $\left({ }^{* *} P<0.01 ;{ }^{* * *} P<0.001\right)$.

the former case no statistically significant differences were found (Fig. 2, part 2; all P>0.05). In contrast to that, the latent enzyme activity in WJ was almost 10 times higher than in the UCAs and over 3 times higher than in the case of the UCV, and that of UCV nearly 3 times higher when compared with the UCAs (Fig. 2, part 3; all $P<0.05$ ).

\section{Latent/active cathepsin B ratio}

The differences among the values of latent CATB activity of all examined tissues largely influence those for the total enzyme; therefore, we decided to assess the latent/active CATB ratios. It is apparent from Fig. 3 that this ratio in the WJ was over 4.5 times high-

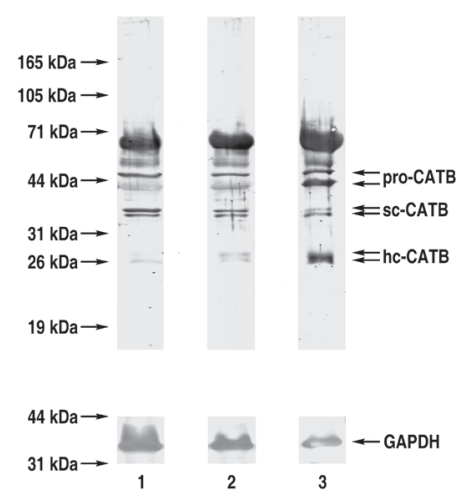

Figure 4. Western immunoblot analysis of cathepsin B in pooled extracts of umbilical cord tissues.

Lane 1, umbilical cord artery; Lane 2, umbilical cord vein; Lane 3, Wharton's jelly. The same amount of protein extract $(20 \mu \mathrm{g})$ was run in each lane. Proteins were separated by SDS/PAGE (10\%) under reducing conditions and immunoblotted with antibodies to human cathepsin B (upper panel) and human GAPDH (lower panel). Molecular masses of various cathepsin B forms were estimated using pre-stained molecular mass markers (catalogue number 1610318; Bio-Rad Laboratories) which were pre-calibrated with low molecular weight (LMW) calibration kit (catalogue number 17-0446-01; Pharmacia) by SDS/PAGE. The positions of molecular mass standards are indicated on the left. Immunolabelled cathepsin B bands are marked on the right: pro-CATB, procathepsin B; sc-CATB, single-chain mature cathepsin B; hc-CATB, heavy chain of fully processed double-chain cathepsin B. Western blot shown is representative of three independent experiments. 


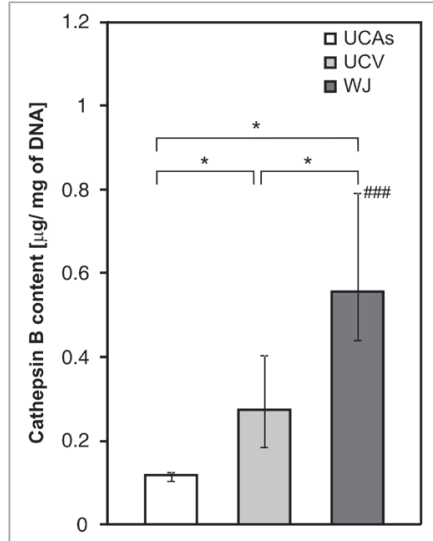

Figure 5. Content of cathepsin B protein in umbilical cord tissues.

The extracts of umbilical cord arteries (UCAs), umbilical cord vein (UCV) and Wharton's jelly (WJ) were assayed by immunoenzymatic method (ELISA). The contents of cathepsin B are calculated per one milligram of DNA contained in umbilical cord tissues. Median values \pm 25 th and 75 th quartiles are presented $(n=10)$. Data are analyzed with Friedman repeated-measures ANOVA (\#\#\#P<0.001), post-hoc comparisons made with the Wilcoxon's signed-ranks test corrected for multiple comparisons using the Bonferroni-Holm method (adjusted $P$-values: ${ }^{*} P<0.05$ ).

er than in the UCAs and above 2 times higher when compared with the UCV (Fig. 3; all $P<0.001$ ).

\section{Expression of cathepsin B protein in the umbilical cord}

Western blot analysis of cathepsin B protein expression in the UC tissue extracts is shown in Fig. 4. Apart from bands of $42-43 / 46 \mathrm{kDa}$, corresponding to procathepsin B (pro-CATB), the bands of two mature forms were detected, including those of single-chain (sc-CATB; 34/35 kDa) and heavy chain of the fully processed double-chain enzyme (hc-CATB; $26 / 27 \mathrm{kDa}$ ), which was or was not glycosylated (Moin et al., 1992). As can be seen, the faster-migrating band of pro-CATB had a slightly higher apparent molecular mass $(43 \mathrm{kDa})$ and was more intensive in WJ extracts (Fig. 4, lane 3) in comparison to that of UC vessels (42 kDa; Fig. 4, lanes 1-2). The 26/27-kDa bands of hc-CATB showed similar distribution of intensity among the UC tissues (Fig. 4). In contrast to that, the bands of mature sc-CATB form in WJ (lane 3) were less prominent than in the UCV (lane 2) and especially in the UCA (lane 1). The other bands of higher molecular mass $(51 \mathrm{kDa}$ and $62 \mathrm{kDa})$ were evenly distributed among the UC tissues (Fig. 4, lanes 1-3) and they probably represent non-specific reaction of the antibodies with CATB-unrelated molecules present in the umbilical cord.

In spite of the equal amounts of protein run on each lane, WJ showed the lowest and the UCAs - the highest expression of GAPDH among the UC tissues (Fig. 4, lower panel, lanes 1-3). These differences were similar to the DNA distribution among these tissues (for comparison see Fig. 1)

\section{Cathepsin B content}

The contents of cathepsin B protein determined by ELISA are presented in Fig. 5. The amount of CATB protein in WJ was almost 5 times higher than in the UCAs and about 2 times higher than in the UCV, and the value for the UCV was almost 2.5 higher when compared with the UCAs (Fig. 5; all $P<0.05$ ).

\section{DISCUSSION}

It is apparent from our present study that CATB content and its total activity, calculated per milligram of DNA, were the highest in WJ and the lowest in the UCAs. The latter parameter was mainly influenced by the activities of the latent, pepsin-activatable enzyme, which showed the highest differences among the examined tissues. These findings were confirmed by Western immunoblotting that showed much higher expression of pro-CATB in WJ than in the UC vessels. Surprisingly, the heavy chain of the mature double-chain form of the enzyme demonstrated similar distribution to that of proCATB and also seemed to contribute to the activity of the latent enzyme (after activation), especially in Wharton's jelly. This phenomenon may be explained by possible interaction with inhibitors, which could co-localise with hc-CATB and prevent its excessive action. Thus, the activity of the mature enzyme could be largely obscured by such inhibitors and only revealed after their degradation by pepsin.

The opposing expression patterns of latent CATB and the cellular protein GAPDH in the UC tissues probably reflect much higher differences in the ability of their cells to synthesize and secrete the enzyme than it could be concluded from the CATB immunoblot alone. We found in this study that the abundance of cells in Wharton's jelly is 4.5 times lower than in UCAs and 2.5 times lower than in UCVs as assessed by DNA assay and calculated per gram of tissue. A similar difference between normal Wharton's jelly and UCAs was reported previously (Sobolewski et al., 2005). It is consistent with previous findings that WJ contains very low number of cells immersed in high amounts of ECM components (Sobolewski et al., 1997; Bańkowski, 1999), whereas the UCV wall features in lower cell content when compared with that of the UCA (Nanaev et al., 1997).

It is apparent from the Western immunoblotting analysis that pro-CATB extracted from WJ tends to have a slightly higher molecular mass (by about $1 \mathrm{kDa}$ ) than in the case of UCV and UCAs. One may speculate that the slightly higher molecular mass of the smaller proenzyme form in WJ might result from more intensive glycosylation or less efficient processing/degradation of saccharide chains in this tissue. This hypothesis, however, awaits confirmation by further studies with the use of deglycosylating enzymes. The double $34 / 35-\mathrm{kDa}$ band of single-chain cathepsin B we obtained in this study corresponds to the single $33-\mathrm{kDa}$ band detected in various human tissues (Hanewinkel et al., 1987; Mach et al., 1992; Eiján et al., 2003). In some studies, however, a double band was detected (Ryan et al., 1995; Hamer et al., 2009). We suggest that the slightly higher molecular mass of the single-chain enzyme from the UC may be a consequence of tissue-specific, less extensive deglycosylation/ processing of pro-CATB and/or anomalously low mobility of sc-CATB in our SDS/PAGE gel system.

The results presented here suggest that the few cells of Wharton's jelly are stimulated to produce larger amounts of various forms of cathepsin B, mainly the latent form of the enzyme, in comparison to the other tissues of the umbilical cord. It is of interest that WJ is proportionally richer in latent CATB than the UC vessels. It contrasts with the previous findings for the aspartic protease cathepsin D that was relatively less abundant in WJ and its total activity in this tissue was only similar to that of the UCAs. Moreover, whereas the latent cathepsin D activity appeared to be the highest in WJ, it constituted a small fraction of the total enzyme activity, and only slightly 
differed from that of the UC vessels (Galewska et al., 2005).

Only a small fraction of the latent cathepsin B is secreted by default into the extracellular fluid, although the liberation of newly synthesized pro-CATB can be increased in response to viral transformation (Achkar et al., 1990), malignant dedifferentiation (Qian et al., 1989) or inflammation (Mort et al., 1984). It is known from recent papers (Mitchell et al., 2003; Weiss et al., 2003; Wang et al., 2004) that some stromal cells of WJ have properties of potentially multipotent stem cells. Under suitable conditions, they can differentiate into cardiomyocytes or into cells of adipogenic, osteogenic (Wang et al., 2004) and neural (Mitchell et al., 2003) lineages. Therefore it cannot be excluded that, as in the case of tumour cells, the low differentiation level of WJ cells is one of the reasons of the relatively high expression of latent CATB, including the proenzyme, in this tissue. There is also some evidence that mesenchymal stem cells, able to differentiate into (at least) adipocytes and osteoblasts, are also present within the UCV endothelial/subendothelial layer (Romanov et al., 2003). Such a phenomenon might then explain the intermediate expression of latent CATB in this tissue.

Distribution of CATB, especially of its latent form, positively correlated with the amount of collagen in the UC as it was previously reported that Wharton's jelly contains about 4 times more (Sobolewski et al., 1997) and UCV contains 3 times more collagen (Romanowicz \& Sobolewski, 2000) in comparison with the UCA wall. It is of interest that the expression and secretion of pro-CATB may be induced by collagen-cell interactions (Koblinski et al., 2002). Moreover, cultured hepatic stellate cells were reported to secrete substantial amounts of apparently double chain form of the enzyme upon transformation into myofibroblasts (Moles et al., 2009). The cells of WJ were previously described as myofibroblasts (Takechi et al., 1993; Kobayashi et al., 1998), therefore one may suppose that their phenotypic properties are responsible for preferential accumulation of fully processed 26/27-kDa form of mature CATB apart from the proenzyme. Additionally, it cannot be excluded that UCV cells similarly respond to collagen as they showed a higher latent CATB activity than the UCA walls, which contain a much lower amount of this protein (Romanowicz \& Sobolewski, 2000).

There is some evidence that cathepsin B can be involved in direct activation of growth factors, such as TGF-31 (Guo et al., 2002; Andl et al., 2010). There is also evidence that in hepatic stellate cells CATB can increase TGF- $\beta 1$ expression (Moles et al., 2009). On the other hand, increased levels of the enzyme have been suggested to be caused by changes in TGF- $\beta$ /BMP signalling, mainly stimulation with TGF- $\beta 1$ (Reisenauer et al., 2007).

Moreover, some other cytokines, including PDGF, were proved to stimulate CATB secretion by cultured synovial fibroblasts (Lemaire et al., 1997). It has been previously described (Sobolewski et al., 2005; Małkowski et al., 2008) that WJ is a reservoir of many peptide growth factors, including TGF- $\beta 1$ and PDGF. The concentration of the former (calculated per microgram of DNA) is 42-fold higher than in the UCA (Sobolewski et al., 2005). It has been suggested that the very sparse WJ cells are strongly stimulated by peptide growth factors such as TGF- $\beta$ to produce large amounts of collagen and glycosaminoglycans (Sobolewski et al., 2005). One cannot exclude that the accumulation of this growth fac- tor is also responsible for the increased production of cathepsin B in Wharton's jelly.

A variety of pregnancy-associated syndromes, including stricture and torsion of the umbilical cord, gestational diabetes or preeclampsia may result from morphological and biochemical alterations in the umbilical cord vessels and in Wharton's jelly (Bańkowski, 1999). One cannot exclude that the abnormal action of various proteases, including cathepsin B, may at least partly contribute to the changes in the amount and structure of various proteins within the UC tissues, e.g., to collagen accumulation in the UCAs in preeclampsia (Bańkowski et al., 1994; Bańkowski, 1999). In this paper, we present the distribution of cathepsin B in the umbilical cord for the first time. Although the results of our study concern healthy individuals, they may facilitate future research explaining several aspects of various prenatal pathologies.

\section{Acknowledgemets}

The study was supported by the Medical University of Białystok, Project No. 3-15 602L.

\section{REFERENCES}

Achkar C, Gong QM, Frankfater A, Bajkowski AS (1990) Differences in targeting and secretion of cathepsins $B$ and L by BALB/3T3 fibroblasts and Moloney murine sarcoma virus-transformed BALB/3T3 fibroblasts. J Biol Chem 265: 13650-13654.

Andl CD, McCowan KM, Allison GL, Rustgi AK (2010) Cathepsin $\mathrm{B}$ is the driving force of esophageal cell invasion in a fibroblastdependent manner. Neoplasia 12: 485-498.

Baici A, Lang A, Zwicky R, Müntener K (2005) Cathepsin B in osteoarthritis: uncontrolled proteolysis in the wrong place. Semin Arthritis Rheum 34: 24-28.

Bańkowski E (1999) Collagen of the umbilical cord and its alteration in EPH-gestosis (preeclampsia). Proc Indian Acad Sci (Chem Sci) 111: 207-213.

Bańkowski E, Romanowicz L, Jaworski S (1994) Alterations in collagen of umbilical cord arteries in patients with EPH-gestosis. Acta Biochim Pol 41: 170-173.

Barrett AJ, Kirschke H (1981) Cathepsin B, cathepsin H and cathepsin L. Methods Enzymol 80: 535-561.

Bradford MM (1976) A rapid and sensitive method for the quantitation of microgram quantities of protein utilizing the principle of protein-dye binding. Anal Biochem 72: 248-254.

Cavallo-Medved D, Sloane BF (2003) Cell-surface cathepsin B: understanding its functional significance. Curr Top Dev Biol 54: 313-341.

Chan SJ, San Segundo B, McCormick MB, Steiner DF (1986) Nucleotide and predicted amino acid sequences of cloned human and mouse preprocathepsin B cDNAs. Proc Natl Acad Sci USA 83: 7721-7725.

Downs TR, Wilfinger WW (1983) Fluorometric quantification of DNA in cells and tissue. Anal Biochem 131: 538-547.

Eiján AM, Sandes EO, Riveros MD, Thompson S, Pasik L, Mallagrino H, Celeste F, Casabé AR (2003) High expression of cathepsin B in transitional bladder carcinoma correlates with tumor invasion. Cancer 98: 262-268.

Galewska Z, Bańkowski E, Romanowicz L, Gogiel T, Wolańska M, Jaworski S (2005) Preeclampsia-associated reduction of cathepsin D activity in the umbilical cord. Clin Chim Acta 351: 177-184.

Gogiel T, Bańkowski E, Jaworski S (2003) Proteoglycans of Wharton's jelly. Int J Biochem Cell Biol 35: 1461-1469.

Guo M, Mathieu PA, Linebaugh B, Sloane BF, Reiners JJ Jr (2002) Phorbol ester activation of a proteolytic cascade capable of activating latent transforming growth factor- $\beta$. A process initiated by the exocytosis of cathepsin B. I Biol Chem 277: 14829-14837.

Hamer I, Delaive E, Dieu M, Abdel-Sater F, Mercy L, Jadot M, Arnould $\mathrm{T}$ (2009) Up-regulation of cathepsin B expression and enhanced secretion in mitochondrial DNA-depleted osteosarcoma cells. Biol Cell 101: 31-41.

Hanewinkel H, Glössl J, Kresse H (1987) Biosynthesis of cathepsin B in cultured normal and I-cell fibroblasts. J Biol Chem 262: 1235112355.

Hill T, Lewicki P (2007) STATISTICS: Methods and applications. StatSoft, Tulsa.

Jacob MP, Badier-Commander C, Fontaine V, Benazzoug Y, Feldman L, Michel JB (2001) Extracellular matrix remodeling in the vascular wall. Pathol Biol 49: 326-332. 
Keppler D, Sloane BF (1996) Cathepsin B: Multiple enzyme forms from a single gene and their relation to cancer. Ensyme Protein 49: 94-105.

Kliman HJ (1998) Umbilical cord. In Encyclopedia of reproduction. Knobil E, Neill J, eds, vol 4, pp 585-596. Academic Press, New York.

Kobayashi K, Kubota T, Aso T (1998) Study on myofibroblasts differentiation in the stroma cells of Wharton's jelly: expression and localization of alpha-smooth muscle actin. Early Human Dev 3: $223-$ 233.

Koblinski JE, Dosescu J, Sameni M, Moin K, Clark K, Sloane BF (2002) Interaction of human breast fibroblasts with collagen I increases secretion of procathepsin B. J Biol Chem 277: 32220-32227.

Laemmli UK (1970) Cleavage of structural proteins during the assembly of the head of bacteriophage T4. Nature 227: 680-685.

Lemaire R, Huet G, Zerimech F, Grard G, Fontaine C, Duquesnoy B, Flipo RM (1997) Selective induction of the secretion of cathepsins $\mathrm{B}$ and $\mathrm{L}$ by cytokines in synovial fibroblast-like cells. $\mathrm{Br} J$ Rheumatol 36: $735-743$.

Mach L, Stüwe K, Hagen A, Ballaun C, Glössl J (1992) Proteolytic processing and glycosylation of cathepsin B. The role of the primary structure of the latent precursor and of the carbohydrate moiety for cell-type-specific molecular forms of the enzyme. Biochem J 282: $577-582$.

Małkowski A, Sobolewski K, Jaworski S, Bańkowski E (2008) TGF-beta binding in human Wharton's jelly. Mol Cell Biochem 311: 137-143.

Mitchell KE, Weiss ML, Mitchell BM, Martin P, Davis D, Morales L, Helwig B, Beerenstrauch M, Abou-Easa K, Hildreth T, Troyer D, Medicetty S (2003) Matrix cells from Wharton's jelly form neurons and glia. Stem Cells 21: 50-60.

Moin K, Day NA, Sameni M, Hasnain S, Hirama T, Sloane BF (1992) Human tumour cathepsin B. Comparison with normal liver cathepsin B. Biochem J 285: 427-434.

Moles A, Tarrats N, Fernández-Checa JC, Marí M (2009) Cathepsins $\mathrm{B}$ and $\mathrm{D}$ drive hepatic stellate cell proliferation and promote their fibrogenic potential. Hepatology 49: 1297-1307.

Mort JS, Buttle DJ (1997) Cathepsin B. Int J Biochem Cell Biol 29: 715720 .

Mort JS, Recklies A, Poole R (1984) Extracellular presence of the lysosomal proteinase cathepsin B in rheumatoid synovium and its activity at neutral pH. Arthritis Rheum 27: 509-515.
Nanaev AK, Kohnen G, Milovanov AP, Domogatsky SP, Kaufmann P (1997) Stromal differentiation and architecture of the human umbilical cord. Placenta 18: 53-64.

Poręba W, Gawlik K, Gutowicz J (2002) Katepsyna B a proces inwazji nowotworowej. Post Biochem 48: 111-120 (Polish).

Qian F, Bajkowski AS, Steiner DF, Chan SJ, Frankfater A (1989) Expression of five cathepsins in murine melanomas of varying metastatic potential and normal tissues. Cancer Res 49: 4870-4875.

Reisenauer A, Eickelberg O, Wille A, Heimburg A, Reinhold A, Sloane BF, Welte T, Bühling F (2007) Increased carcinogenic potential of myeloid tumor cells induced by aberrant TGF- $\beta 1$-signaling and upregulation of cathepsin B. Biol Chem 388: 639-650.

Romanov YA, Svintsitskaya VA, Smirnov VN (2003) Searching for alternative sources of postnatal human mesenchymal stem cells: candidate MSC-like cells from umbilical cord. Stem Cells 21:105-110.

Romanowicz L, Sobolewski K (2000) Extracellular matrix components of the wall of umbilical cord vein and their alterations in pre-eclampsia. J Perinat Med 28: 140-146.

Ryan RE, Sloane BF, Sameni M, Wood PL (1995) Microglial cathepsin B: an immunological examination of cellular and secreted species. $J$ Neurochem 65: 1035-1045.

Schmitt M, Jänicke F, Graeff H (1997) Tumor-associated proteases. Fibrinolysis 6 (Suppl 4): 3-26.

Skrzydlewska E, Sulkowska M, Koda M, Sulkowski S (2005) Proteolytic-antiproteolytic balance and its regulation in carcinogenesis. World J Gastroenterol 11: 1251-1266.

Sobolewski K, Bańkowski E, Chyczewski L, Jaworski S (1997) Collagen and glycosaminoglycans of Wharton's jelly. Biol Neonate 71: 11-21.

Sobolewski K, Małkowski A, Bańkowski E, Jaworski S (2005) Wharton's jelly as a reservoir of peptide growth factors. Placenta 26: 747752.

Takechi K, Kuwabara Y, Mizuno M (1993) Ultrastructural and immunohistochemical studies of Wharton's jelly umbilical cord cells. Placenta 14: 235-245.

Wang HS, Hung SC, Peng ST, Huang CC, Wei HM, Guo YJ, Fu YS, Lai MC, Chen CC (2004) Mesenchymal stem cells in the Wharton's jelly of the human umbilical cord. Stem Cells 22: 1330-1337.

Weiss ML, Mitchell KE, Hix JE, Medicetty S, El-Zarkouny SZ, Grieger D, Troyer DL (2003) Transplantation of porcine umbilical cord matrix cells into the brain. Exp Neurol 182: 288-299. 